\title{
Creating change in responsible tourism management through social marketing
}

\author{
R. George* and N. Frey \\ School of Management Studies, University of Cape Town, \\ Private Bag, Rondebosch 7701, Republic of South Africa \\ Richard.george@uct.ac.za
}

Received April 2009

\begin{abstract}
The global threat of climate change, diminishing natural resources and significant socio-economic inequalities is forcing companies and individuals to evaluate the impact they are having on the natural, social and economic environments. This trend has led to an increased availability and demand for socially, environmentally and economically responsible products. The tourism industry relies heavily on the sustained beauty and hospitality of the places and communities it operates in and has come under pressure to manage its negative impacts. Change in the industry has, however, been limited. This paper investigates the current attitudes and perceptions of tourism business owners in Cape Town towards responsible tourism management (RTM) practices in order to develop social marketing strategies that can influence positive behaviour change in management. Cape Town as an internationally acclaimed top tourism destination needs to urgently address its low levels of responsible tourism evidence. Survey data of 244 tourism businesses was used to statistically test what factors are causing the low levels of RTM practices in Cape Town. Findings suggest that despite general positive attitudes towards RTM, tourism businesses are not investing time and money into changing management practices. This is a common emerging market phenomenon where resource constraints negatively impact the relationship between what businesses would like to do and what actually gets done. Factors such as the perceived cost of RTM, a highly competitive environment and a perceived lack of government support are further negatively influencing this relationship. Recommendations are made as to how social marketing can be used to encourage businesses to adopt RTM practices by reducing the perceived and actual costs of implementing RTM. The paper discusses what channels should be implemented to facilitate change.
\end{abstract}

*To whom all correspondence should be addressed.

\section{Introduction}

In the global business sector corporate social responsibility (CSR), corporate social investment (CSI) and ethical management practices have emerged as strong trends. Evidence of actual change in the tourism industry, however, remains relatively limited (Wheeler, 1995; Goodwin \& Venu, 2008: 2). Since the Brundtland Report of 1987 (UN, 1987) proposed that intergenerational equality would not be achieved unless the impacts of economic activity on the environment were managed, both debate and research into sustainable tourism practices and philosophies have increased. Concern for sustainable tourism arose from the realisation that mass tourism could have significant negative environmental impacts in destinations if it was not controlled (Budeanu, 2005; Spenceley, 2005). At the 1992 United Nations Conference on Environment and Development it was recognised that tourism would be an important driver in community upliftment. As the debate surrounding sustainable development intensified, South Africa responded with the 1996 White Paper 'Development and Promotion of Tourism in South Africa'. The White Paper in no uncertain terms outlined that for South Africa, responsible tourism was not a luxury but a necessity. During 2001, the Responsible Tourism Manual for South Africa (RTMSA) and the Responsible Tourism Guidelines (DEAT, 2002) were developed. The first conference on Responsible Tourism was hosted in Cape Town in 2002 prior to the World Summit on Sustainable Development (WSSD) held in Johannesburg that same year. The Responsible Tourism conference led to the 'Cape Town Declaration' where responsible tourism was defined as a three-tiered approach: firstly, tourism development should increase the quality of life for surrounding communities; secondly it should create better business opportunities; and thirdly, improved experiences for tourists. Fundamental to this approach is the co-operation of communities and the public and private sector. Globally, South Africa's responsible tourism initiatives were seen as progressive. However, eight years later, the question is increasingly being asked to what degree the Cape Town Declaration and the Responsible Tourism Guidelines (DEAT, 2002) have been adopted by the industry and have led to revised management practices. The 2008 Second International Conference on Responsible Tourism in Destinations hosted in Kerala, India, highlighted the need for increased government and private sector commitment to responsible tourism implementation, the lack of good measurement systems for impact assessment and the necessity for the debate to move towards addressing responsible tourism in a more strategic rather than moralistic manner (Goodwin \& Venu, 2008: 2). 
There is a clear need for effective change channels through social marketing practices. Social marketing is defined as "a program planning process that promotes the voluntary behaviour of target audiences by offering relevant benefits, reducing barriers, and using persuasion to motivate participation in program activity" (Kotler \& Roberto, 1989: 24). Essentially social marketing is about encouraging a change in behaviour in certain groups of people. An underlying condition of successful social marketing strategies is an understanding of what the perceived costs and benefits of the proposed behaviour change, in this case adoption of RTM, are (Robinson, 1998; Rothschild, 1999; Andreasen, 2000).

Increased attention, research and literature in the field of responsible management, sustainable development and related topics have led to the emergence of a plethora of definitions in the field. Whereas responsible, eco- and sustainable tourism should not be used interchangeably, the approaches all have a common objective of minimising negative social, economic and environmental impacts, whilst maximising the positive effects of tourism development. Table 1 provides several definitions in this subject area, as well as highlighting the specific focus each one of them has. For the purpose of this paper, the working definition for responsible tourism management (RTM) is: 'managing the business in a way that benefits its local community, natural and business environment and itself'.

\section{Objectives of the study}

The purpose of this research is to examine the relationship between tourism business managers' attitudes and perceptions towards responsible tourism management and businesses behaviour with regards to responsible tourism management in the emerging market context of the Cape Town tourism industry. The analysis aims to highlight the factors that are disrupting or enhancing the relationship between attitude and behaviour in order to develop effective social marketing strategies to affect change.

\section{A review of responsible tourism research in South Africa}

Tourism as one of the biggest industries in the world and in Africa is seen as having the potential to address many of the socio-economic challenges facing the continent. The New Partnership for Africa Development's (NEPAD) Tourism Action Plan states that "tourism is recognised as one of the sectors with the most potential to contribute towards the economic regeneration of the continent, particularly through the diversification of African economies" (Rogerson \& Visser, 2004: 3). At the 1998 Job Summit in Johannesburg, the tourism sector was seen as having the greatest potential to reduce the high levels of unemployment (Rogerson \& Visser, 2004: 4). In 2008 9, 59 million international tourists visited South Africa (South African Tourism, 2009). Tourism contributed over R140billion or $8.2 \%$ to the South African gross domestic product (GDP) and created 1041700 jobs (7.4\% of the country's total employment figure) (South African Tourism, 2009). Tourism is clearly a growing sector contributing considerably to the country's economy. Multi-stakeholder inclusion in tourism development, however, has not always been the norm in South Africa and still today various obstacles present themselves in building a truly representative tourism sector.

Tourism in Africa was historically first developed 'by colonialists for colonialists' and only recently is tourism seen as a development tool (Scheyvens, 1999; Rogerson \& Visser, 2004: 2). During the apartheid years (1948 - 1990) tourism was 'non-developmental', leading to a nonrepresentative distribution in product ownership. In the past, most black South Africans did not participate in, nor benefit from the formal tourism sector. This has led to a large proportion of the community not having a stake in the ownership of the national tourism product, leading to misrepresentation and hostility towards the sector (Allen \& Brennan, 2004: 9). In 2005, the Tourism Black Economic Empowerment (BEE) Charter and Scorecard, a Department of Environmental Affairs and Tourism (DEAT) initiative was formed to promote the rate of transformation in the South African tourism industry. Companies were encouraged to address management areas of ownership, strategic representation, employment equity, skills development, preferential procurement, enterprise development and corporate social investment. This would then lead to BEE accreditation and subsequent government tenders. Besides the South African imperative to reduce inequality, tourism, perhaps more so than any other industry, has an obvious interest in following socially responsible principles as it is highly dependent on cultural heritage and the sustained beauty of natural resources (Dolnicara \& Leisch, 2008). Notwithstanding, research, as discussed below, shows that the South African tourism industry has been slow to adopt the principles of social responsibility (Martin \& Jucker, 2005; Wijk \& Persoon, 2006). 
Table 1: Definition of sustainable tourism-related terms.

\begin{tabular}{|c|c|c|c|}
\hline Term & Definition & By & Emphasis \\
\hline 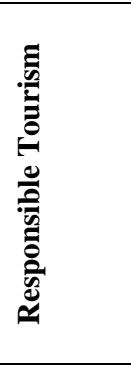 & $\begin{array}{l}\text { Responsible Tourism is about providing better holiday } \\
\text { experiences for guests and good business opportunities to } \\
\text { enjoy better quality of life through increased socio- } \\
\text { economic benefits and improved natural resource } \\
\text { management. }\end{array}$ & 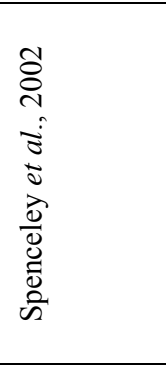 & $\begin{array}{l}\text { 1. Develop a competitive advantage; } \\
\text { 2. Assess, monitor and disclose } \\
\text { impacts of tourism development; } \\
\text { 3. Ensure involvement of communities } \\
\text { and the establishment of meaningful } \\
\text { economic linkages; } \\
\text { 4. Encourage natural, economic, social } \\
\text { and cultural diversity; } \\
\text { 5. Promote the sustainable use of local } \\
\text { resources. }\end{array}$ \\
\hline 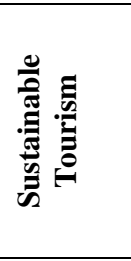 & $\begin{array}{l}\text { Sustainable tourism means achieving a particular } \\
\text { combination of numbers and types of visitors, the } \\
\text { cumulative effect of whose activities at a given destination, } \\
\text { together with the actions of the servicing businesses, can } \\
\text { continue into the foreseeable future without damaging the } \\
\text { quality of the environment on which the activities are } \\
\text { based. }\end{array}$ & 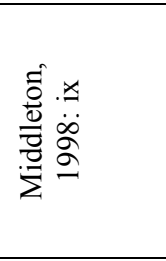 & $\begin{array}{l}\text { The responsible management of } \\
\text { resources for the use and enjoyment of } \\
\text { present and future generations. }\end{array}$ \\
\hline 冚 & $\begin{array}{l}\text { Ethical tourism is a concept that goes beyond the three } \\
\text { principles of sustainability. It recognises that tourists and } \\
\text { tourism providers must take some responsibility for their } \\
\text { behaviour and attitudes, with each stakeholder group } \\
\text { gaining equity in the tourism decision-making process. }\end{array}$ & 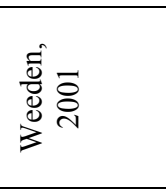 & $\begin{array}{l}\text { Tourists and tourism providers have a } \\
\text { moral responsibility for their actions. }\end{array}$ \\
\hline 章 & $\begin{array}{l}\text { Travelling to relatively undisturbed or uncontaminated } \\
\text { natural areas with the specific objective of studying, } \\
\text { admiring and enjoying the scenery and its wild plants and } \\
\text { animals, as well as any existing cultural manifestations } \\
\text { (both past and present) found these areas. }\end{array}$ & 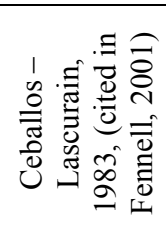 & $\begin{array}{l}\text { 1. Provides for environmental } \\
\text { conservation, } \\
\text { 2. Includes meaningful community } \\
\text { participation, } \\
\text { 3. Is profitable and can sustain itself. }\end{array}$ \\
\hline 苞 & $\begin{array}{l}\text { Tourism that respects natural and built environments...the } \\
\text { heritage of people and place. }\end{array}$ & 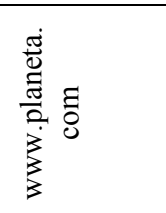 & $\begin{array}{l}\text { Respect for the local natural environment } \\
\text { and local heritage is emphasised. }\end{array}$ \\
\hline 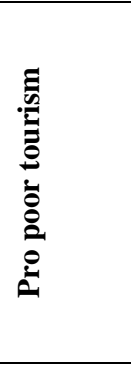 & $\begin{array}{l}\text { Pro-Poor tourism is not a specific tourism product; it is an } \\
\text { approach to tourism development and management which } \\
\text { ensures that local poor people are able to secure economic } \\
\text { benefits from tourism in a fair and sustainable manner. }\end{array}$ & 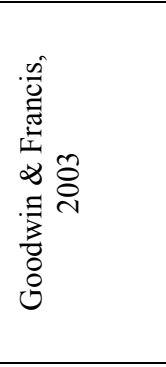 & $\begin{array}{l}\text { Pro-poor tourism may improve the } \\
\text { livelihoods of poor people in three main } \\
\text { ways: } \\
\text { 1. Economic gain through employment } \\
\text { and micro-enterprise development; } \\
\text { 2. Infrastructure gains: roads, water, } \\
\text { electricity, telecommunications, } \\
\text { waste treatment; } \\
\text { 3. Empowerment through engagement } \\
\text { in decision making. }\end{array}$ \\
\hline 䒴 & $\begin{array}{l}\text { Alternative tourists aim to put as much distance as possible } \\
\text { between themselves and mass tourism. }\end{array}$ & 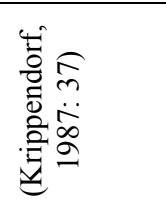 & $\begin{array}{l}\text { Alternative tourism focuses on } \\
\text { individualism and having a unique and } \\
\text { authentic experience by interaction with } \\
\text { the local community and environment. }\end{array}$ \\
\hline
\end{tabular}

Spenceley (2007) replicated the 2001 Tearfund study to evaluate to what extent South African tour operators were engaging in responsible management practices. Spenceley surveyed a sample of 20 predominantly small-sized tour operators attending the 2006 Tourism Indaba (an annual travel trade show in Durban). A self-administered survey included questions on partnerships, local benefits, training, policies, and consumer demand for responsible tourism. Spenceley's study revealed that $66 \%$ of tour operators claimed to have positive impacts on local communities. These took the form of employment creation, using local service providers and purchasing local products (Spenceley, 2007: 3). However, the research also found that tour operators faced numerous barriers in bringing benefits to local people. Concerns about crime, accessibility and problems relating to skills, consistent service quality and language capacity were raised. Furthermore, the study revealed that only half of respondents claimed to have 
responsible tourism policies in place (Spenceley, 2007: 8). A majority of the sampled tour operators, however, indicated that they were engaging in positive interventions in local communities. Benefits to the community ranged from economic upliftment through employment opportunities, to improved local infrastructure and support for education, and health and conservation initiatives (Spenceley, 2007: 8).

Van der Merwe and Wöcke (2007) researched the level of responsible tourism practices in the South African hotel sector. The aim of the study was to uncover the level of understanding regarding corporate social responsibility (CSR) and the extent to which practices from the Responsible Tourism Guidelines (DEAT, 2002) were being implemented. The study found that, on average, South African hotels were implementing $47 \%$ of the economic guidelines, $45 \%$ of the social elements and $40 \%$ of the guidelines were encouraging general responsible behaviour. A high percentage of the sample did not use CSR in their marketing campaigns and had not set any measurable targets (Van der Merwe \& Wöcke, 2007). The research sample included a significant number of hotels that belong to associations promoting responsible tourism (such as Fair Trade in Tourism South Africa) or had participated in the Imvelo Responsible Tourism Awards (IRTA). Despite the potentially elevated figures these associations would bring, the results of both studies indicate low levels RTM practices.

In 2007, the Tourism Empowerment Council of South Africa (TECSA) commissioned an investigation into this lack of transformation in the South African tourism sector. The study revealed that larger tourism businesses - with an average annual turnover of R14 billion - were, in general, meeting 2006 transformation targets, although often falling short of 2009 goals. TECSA found that companies were underperforming in the areas of strategic representation especially of black women $(60 \%$ of respondents below target) and preferential procurement (25\% below target). In addition, the transformation study found that $80 \%$ of small and medium-sized companies were struggling to meet most 2006 and 2009 targets. Thus, transformation in the small business tourism sector is extremely limited. Reasons for this include the difficultly that small businesses have in reaching the BEE targets, a perception that government tenders do not apply to small businesses and therefore are of no benefit, and a lack of understanding of the seemingly complicated and expensive accreditation process (Yarona Management Consulting, 2007).

\section{Corporate social responsibility}

Responsible tourism management (RTM) can be categorised under the more general themes of corporate social responsibility (CSR) and corporate social investment (CSI). Research into CSR has increased over the last 12 years as the global community demands that companies look beyond profit maximisation and include social and environmental objectives in their management strategies
(Robin \& Reidenbach, 1987; Maignan \& Ferrell, 2004; Frey, 2007: 319). CSR, according to the World Tourism and Travel Council (WTTC), means adopting open and transparent business practices that are based on ethical values. The approach strives to manage the various aspects of operations and minimise their negative impacts on the surrounding environment (WTTC, 2006). CSR and CSI attempt to deliver sustainable value to society at large, as well as to shareholders, for the long-term benefit of both (WTTC, 2006: 2). The evidence of positive return on investment (ROI) is in line with the fundamentals of CSI, which views social responsibility as an investment rather than a cost. The scope of CSR includes attempts to: increase community involvement in decision-making, build mutually beneficial partnerships with communities to decrease economic leakages, provide employment opportunities, revise investment policies and relations with investors, address corruption, comply with governmental regulations, improve relations with suppliers and marketing intermediaries, advertise honestly, implement fair pricing policies, provide equal opportunities and remuneration, reduce waste, and increase sustainable management of scarce natural resources (Hunt, Wood \& Chonko, 1989; Maignan \& Ferrell, 2004; Pender \& Sharpley, 2005: 196; Porter \& Kramer, 2006).

Active employee and management involvement, commitment of resources and time by all stakeholders is needed to reap the benefits of CSR (Pender \& Sharpley, 2005: 289). In most cases the literature indicates that the ROI of CSR is positive and that business performance is improved in the medium- to long-term (for example, see Becker-Olsen, Cudmore \& Hill, 2006; Sen \& Bhattacharya, 2001). To reap the rewards of CSR, certain changes in management are necessary. Attitude and intention are two of the main influencers on behaviour and impact management style (Blackwell, Miniard \& Engel, 2006: 87).

There are three main forces that have contributed to the growth in CSR, these are as follows:

1. Global pressure on companies to manage responsibly has increased. Governments, activists and the media are holding companies accountable for the social, environmental and economic consequences of their operations (Porter \& Kramer, 2006);

2. Consumers are beginning to demand goods and services from companies that attempt to manage their social, environmental and economic impacts; and

3. The increase in CSR awareness and application has led to a wide body of academic literature and professional experience in this field. The evidence shows that a range of business benefits can accrue to companies that manage their businesses responsibly. In a highly competitive environment such differentiating factors are providing an incentive for 
businesses to adopt CSR principles (Porter \& Kramer, 2006; Bellows, 2007).

In this study, CSR served as a platform from which to generate hypotheses and develop the conceptual model applied to tourism.

\section{Emerging markets}

There is no single definition of what constitutes an emerging market. Some common characteristics however, can be identified. Burgess and Steenkamp (2006) combine the various definitions of financial institutions (ING and Morgan Stanley), the World Trade Organisation (WTO) and the United Nations (UN) to state that emerging markets are "countries in which purchase power parity (PPP), adjusted GDP per capita, converted to US\$ and smoothed for three-year currency fluctuations, is equal or less than the highest ranked country classified as 'middle income' by the World Bank" (Burgess \& Steenkamp, 2006). EMs are characterised by high GDP growth and significant social reform (Hoskisson, Eden, Chung \& Wright, 2000).

The increased rate of globalisation and the consequent international competition has led to the testing of theoretical concepts in EMs. International trade barriers have been reduced and markets are more open than ever before. Many developed markets, including the USA and EU are trading with less advanced economies where input resources are relatively cheaper. This growth in international trade has led to the development, as well as exploitation of many EMs. Consequently research is required to better inform marketing strategy and management (Schianetz, Kavanagh, \& Lockington, 2007). Burgess and Steenkamp (2006) found significant differences exist in the application and generalisability of marketing theories in these new environments. In particular, challenges related to data collection and interpretation were identified resulting in the shorting and simplification of measurement scales (for example using 5point instead of 7-point Likert scales). There is, thus, a need to test previously established constructs from highly industrialised countries (HICs) in EMs.

\section{The relationship between attitude, intention and behaviour}

Ruekert (1992), Jaworski and Kohli (1993) and Maignan, Ferrell \& Hult (1999) found that management attitude influences:

a) management intention (i.e. committing resources to implement change);

b) financial and non-financial business performance; and

c) organisational commitment.
In order to investigate why the South African tourism industry is experiencing such low levels of RTM, the relationships between RTM attitude, intention and subsequent behaviour had to be tested. Management attitude was therefore included as the main antecedent in the conceptual model of the study (see Figure 1). This construct is comprised of three scales measuring: (i) perceptions and attitudes towards ethics and social responsibility (PRESOR) (Singhapakdi, Vitell, Rallapalli \& Kraft ,1996); (ii) corporate citizenship (Jaworski \& Kohli, 1993); and (iii) attitude towards RTM. This led to the formulation of the following primary hypotheses:

Hypothesis $_{1}$ : There is a direct positive statistical relationship between management attitude and responsible management intention.

Hypothesis $_{2}$ : There is a direct positive statistical relationship between management attitude and business performance.

Hypothesis $_{3}$ : Responsible management intention has a direct positive effect on business performance.

Maignan, Ferrell and Hult (1999) tested four responsibility dimensions, referred to as corporate citizenship, and developed measurement scales for each one of them. Specifically, the research examined the statistical relationship between the commitment of marketing practitioners towards corporate citizenship and the effect this had on business benefits. Two independent samples were used to validate their findings. The achieved sample of the first group consisted of 229 member companies of the American Marketing Association (AMA). The second sample was comprised of $154 \mathrm{MBA}$ students from different parts of the USA. Maignan et al. (1999) found that proactive corporate citizenship leads to higher levels of marketing orientation (MO), which, in turn, is associated with business benefits, including "improved levels of employee commitment, customer loyalty and business performance" (Maignan et al., 1999; Kirca, 2006). Corporate citizenship can, therefore, lead to improved management practices which result in a positive ROI. Constructs measuring the perceived role of CSR, corporate citizenship and RTM were included in the conceptual model to establish the nature of this relationship in an emerging and tourism market. Combined, they serve as an indicator of management attitude which, in turn, leads to management intention (a subscale of MO) (Rueckert, 1992). Attitude is classically described as a consistent favourable or unfavourable feeling, response towards, or evaluation of an object or class of objects (Allport, 1935, as cited by Pizam \& Mansfeld, 1999: 104; Ajzen \& Fishbein, 1980: 27, as cited by Allen, Machleit, Kleine \& Notani, 2005). The choice of how to respond, be it in a purchasing or management situation, is influenced by attitude and perception (Pizam \& Mansfeld, 1999: 105). 


\section{Moderators}

In line with previous research the effect of various moderators on management attitude, intention and performance was also tested; moderators negatively or positively influence the strength of the tested relationships. Moderators in the study included the competitive environment, the size and years of operation of the business and the personal values of managers (Jaworski \& Kohli, 1993; Maignan et al., 1999; Schwarz, 2004; Burgess \& Steenkamp, 2006; Yaman \& Gurel, 2006).

The variables of interest that were tested are shown in Table 2.

\section{Table 2: Variables of interest}

\begin{tabular}{l|l|l}
\hline $\begin{array}{l}\text { Dependent } \\
\text { Variables }\end{array}$ & $\begin{array}{l}\text { Independent } \\
\text { Variables }\end{array}$ & Moderators \\
\hline $\begin{array}{l}\text { Responsible } \\
\text { management } \\
\text { intention (RMI) }\end{array}$ & CSR (PRESOR) & $\begin{array}{l}\text { Industry } \\
\text { factors/Organisational } \\
\text { Characteristics }\end{array}$ \\
\hline $\begin{array}{l}\text { Organisational } \\
\text { commitment }\end{array}$ & RTM & Values \\
\hline $\begin{array}{l}\text { Financial } \\
\text { performance }\end{array}$ & $\begin{array}{l}\text { Corporate } \\
\text { citizenship }\end{array}$ & \\
\hline $\begin{array}{l}\text { Non-financial } \\
\text { performance }\end{array}$ & $\begin{array}{l}\text { Responsible } \\
\text { management } \\
\text { intention (RMI) }\end{array}$ & \\
\hline
\end{tabular}

The inclusion of these moderator effects led to the formulation of the following hypotheses:

Hypothesis 4 : Industry factors have a negative and positive moderating effect on the statistical relationship between responsible management intention and business performance.

Hypothesis $_{5}$ : Organisational characteristics have a negative moderating effect on the statistical relationship between management attitude and responsible management intention.

Hypothesis $_{6}$ : Organisational characteristics have a negative moderating effect on the statistical relationship between responsible management intention and business performance.

Hypothesis7: Managers' personal values have a positive moderating effect on the statistical relationship between management attitude and responsible management intention.

Performance, as an outcome in the model, was measured using financial as well as non-financial scales. Financial performance was tested using the dichotomous scale developed by Burgess and Nyajeka (2006). Burgess and Nyajeka (2006) conducted a study into market orientation of the low income (base of the pyramid) market in Zimbabwe and developed a dichotomous financial performance scale. Seventy-five Zimbabwean managers from retail outlets were interviewed telephonically. A scale both on attitude towards the role of responsible management and its effect on business performance, as well as an actual financial performance scale was developed and tested for this purpose. This approach differs from the traditional method of gathering data on financial performance, which usually requires respondents to give objective data on company performance in the form of financial documentation. Under ideal circumstances one would gather objective financial performance data .However, in EMs where data is often difficult to attain and lacks accuracy, subjective measures were used extensively. The research findings show that there is a high correlation between subjective and objective measure of performance and hence justified the use of this scale (Burgess \& Nyajeka, 2006).

As a non-financial performance indicator the categories of the BEE Tourism Charter and Scorecard were included in the questionnaire, weighted and added to yield RTM scores. The organisational commitment scale by Hunt et al. (1989) was used as a third performance indicator, as organisational commitment has been shown to lead to increased employee performance.

A study by Gilg, Barr and Ford (2005) found that consumers were more likely to purchase responsibly if they perceived that their act of purchasing (e.g. organic food or fairly traded coffee) made a difference in the environment and future government policies. From a management perspective Yaman and Gurel (2006) noted that tourism decision-makers are more likely to adopt ethical management practices in the case where they believed such actions to be effective. Efficacy is also influenced by an individual's belief that government-led initiatives are effective in achieving set social, economic and environmental objectives (Gilg et al., 2005; Yaman \& Gurel, 2006). The qualitative research findings of this study indicated a high level of distrust towards the South African government's ability to effectively execute programmes and initiatives, as well as a low level of awareness regarding the Responsible Tourism Manual for South Africa (RTMSA) and BEE Tourism Charter and Scorecard. It was hypothesised that the level of understanding and perception of government support towards implementing RTM is likely to play a role in the adoption of RTM and should be tested.

Hypothesis: The level of understanding of tourism businesses of the RTMSA and BEE Tourism Charter and Scorecard is low.

Hypothesis $_{9}$ : There is a positive statistical relationship between the level of knowledge and understanding of government policies and managers' attitudes towards RTM. 


\section{Conceptual model testing the relationship between management attitude and behaviour}

In order to increase the adoption of RTM it is necessary to understand what the current perceptions of the industry are towards CSR and RTM, what factors are impeding this adoption, what the actual level of RTM behaviour is, and how these management attitudes affect business performance (Singhapakdi et al., 1996).

Singhpakdi et al. (1996) developed a scale in the United States of America (USA) to test the perceived role of ethics and social responsibility (PRESOR) for marketers. The scale has been tested in an emerging market context, namely China, and has been found to be reliable (Shafer, Fukukawa, \& Lee, 2007; Etheredge, 1999). Yaman and Gurel (2006) applied the scale in tourism research, investigating the ethical ideologies of tourism marketers. The authors compared the results from an emerging market (Turkey) with those from a highly industrialised country (Australia) and found that significant differences exist. Turkish managers were found to be more idealistic and relativistic compared to their Australian counterparts. Cultural differences were found to be the main reason for these discrepancies.

Management style and attitude in turn have been shown in numerous contexts to influence performance (Ruekert, 1992; Jaworski \& Kohli, 1993; Maignan, Ferrell \& Hult, 1999). The conceptual model developed in this study aims to explore the relationships between attitudes towards CSR and RTM, management intention and business performance in the Cape Town tourism industry. The conceptual model is based on the combination of these previously tested statistical relationships.

\section{Social marketing}

In order to encourage the tourism industry to transform and remain competitive in the light of global trends, change agents are necessary. A tool that can be used to influence behaviour change is social marketing. Social marketing is defined as "a program planning process that promotes the voluntary behaviour of target audiences by offering benefits they want, reducing barriers they are concerned about, and using persuasion to motivate their participation in program activity" (Kotler \& Roberto, 1989: 24). Essentially social marketing is about encouraging a change in behaviour in certain groups of people. An underlying condition of successful social marketing strategies is an understanding of what the perceived costs and benefits of the proposed behaviour change, in this case adoption of RTM, are (Robinson, 1998; Rothschild, 1999; Andreasen, 2000).

Singhapakdi et al. (1996) recommend that to increase the adoption of responsible and ethical management practices a deep understanding of the current perceptions of CSR in tourism is necessary. The generated hypotheses were therefore used to develop the conceptual model, which was statistically tested using multiple regressions, as well as exploratory factor analysis. The model is shown in Figure 1.

\section{Research methodology}

The research design comprised an exploratory and descriptive phase. Three focus groups with members of Cape Town Tourism (CTT) were conducted to refine scale items and discuss relevant issues pertaining to the study. CTT is a regional tourism organisation (RTO), whose role is the provide information to tourists and promote local tourism businesses. CTT is government-funded and membership-driven. Businesses applying for membership need to comply with the minimum quality requirements set out by CTT. Valuable insight was gained from the focus group discussion. Questions in the survey were subsequently adapted to reflect the particular views of the Cape Town tourism industry. For the descriptive research phase, a survey was developed and checked for content and face validity. The survey instrument was pilot tested and after making minor changes e-mailed to a database of 1700 CTT members. De Jong, Steenkamp, Fox and Baumgartner (2008) found that there are no differences in results when using online or pencil-and-paper questionnaires. Moreover, the significant growth of the Internet as a research tool, its proven reliability and the business environment the target population operates in, justified the use of this method (Brennan, Rae \& Parackal, 1999; Wharton et al., 2003; Morris, Fenton \& Mercer, 2004; Fricker et al., 2005; Roth, 2005). A final response rate of $14 \%(n=244)$ was achieved. This is in line with other research in EMs and is deemed a large enough sample to be able to test hypotheses with (Jaworski \& Kohli, 1993; Etheredge, 1999; Cooper \& Schindler, 2006: 445).

\section{New responsible tourism management scale development}

There is currently no satisfactory scale in use that measures the perceived costs and benefits of RTM. Therefore, for the purpose of this research a new scale was developed using the framework provided by Maignan et al. (1999). A large pool of potential items was first generated using literature and expert sources. These were reduced to 35 -scale items. The construct was then tested for content validity by pilottesting the questionnaire with experienced professionals and academics from the fields of marketing, marketing research and tourism. The questionnaire was also sent to a professional research house to compare and validate the standard of the questionnaire with that used in the market research industry. Based on the feedback several scale items were edited, eliminated and new ones were added. In particular, the negatively-worded questions were changed to positive wording, as respondents found negatively phrased questions difficult to answer. The final RTM scale comprised nine scale items and was tested once more with academics and marketing professionals. 


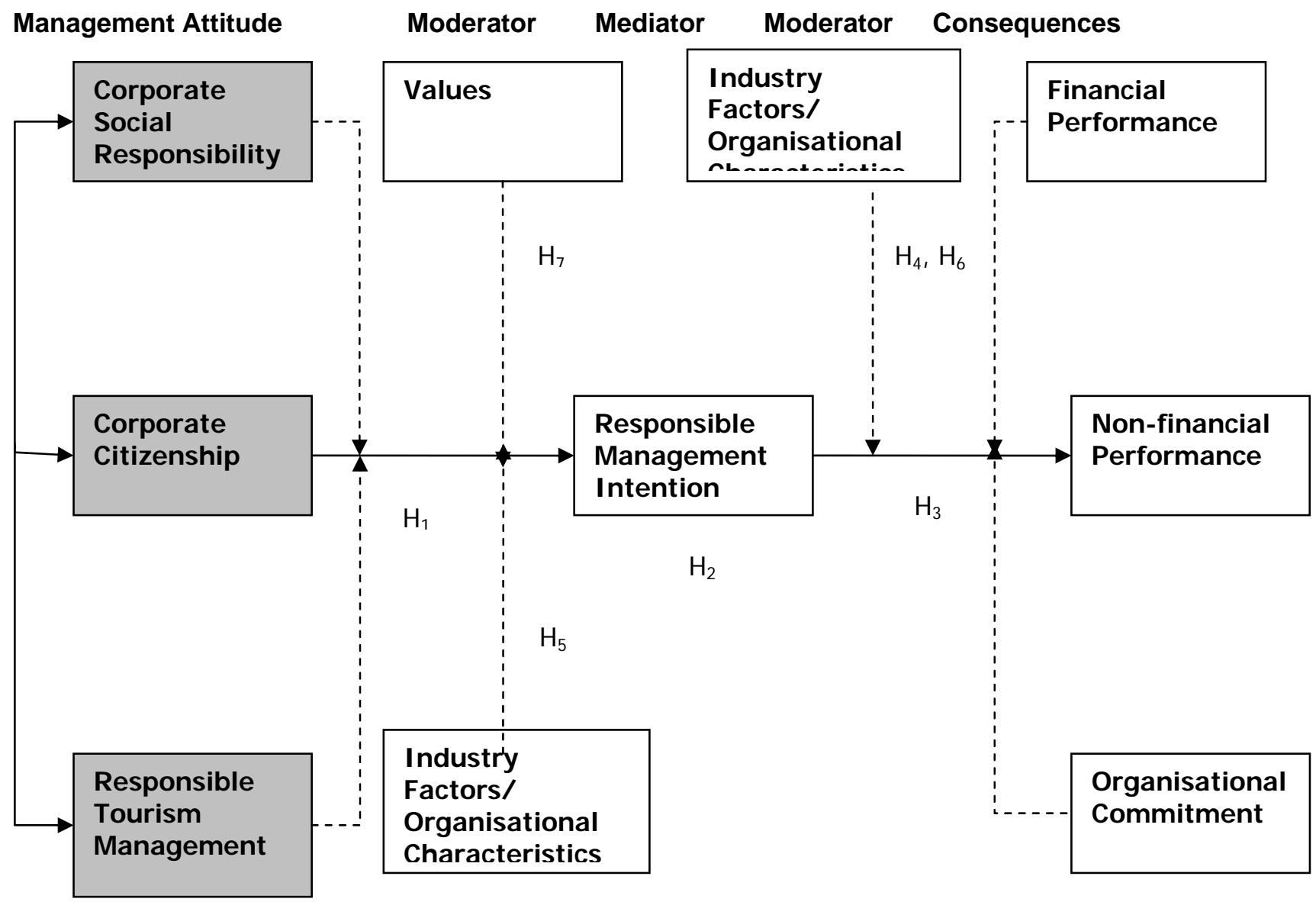

Figure 1: Conceptual framework of the effect of management attitude on performance.

\section{Research findings}

Cronbach's alpha coefficients and total inter-item correlation were used to test for reliability of scales. All scales, except the sub-set of the Schwartz (1994) value scales had a Cronbach's alpha of 0.6 or higher (see Table 3 ). According to Burgess and Steenkamp (2006) this is an acceptable level in emerging market research. A factor analysis was then run to reduce the data for testing.
Table 3: Cronbach's alpha reliability scores for measured constructs

\begin{tabular}{|c|c|c|c|}
\hline & $\begin{array}{c}\text { Cronbach's } \\
\text { alpha }\end{array}$ & $\mathbf{N}$ & Items \\
\hline $\begin{array}{l}\text { Perceived role of ethics and } \\
\text { social responsibility (PRESOR) } \\
\text { Corporate citizenship } \\
\text { Responsible tourism } \\
\text { management (RTM) (new } \\
\text { scale) } \\
\text { Responsible management } \\
\text { intention (adapted scale) } \\
\text { Financial performance } \\
\text { Organisational commitment } \\
\text { Values (tradition and } \\
\text { conformity) } \\
\text { Competitive environment }\end{array}$ & $\begin{array}{l}0,7 \\
\\
0,7 \\
0,7 \\
0,86 \\
\\
0,59 \\
0,68\end{array}$ & $\begin{array}{l}201 \\
\\
199 \\
194 \\
198 \\
\\
201 \\
196\end{array}$ & $\begin{array}{l}9 \\
4 \\
3 \\
4 \\
\\
6 \\
7\end{array}$ \\
\hline
\end{tabular}


Analysis of the study data shows that the direct positive statistical relationship between attitude and behaviour as suggested by the consumer behaviour literature does not hold. The main reason for this missing link is the lack of responsible management intention (RMI), which is the willingness of tourism managers to commit resources into changing management practices. RMI, thus, completely mediates the statistical relationship between CSR orientation and financial performance; the perceived costs of RTM and non-financial performance; and corporate citizenship and non-financial performance. The results of this study highlight that a positive attitude towards RTM does not necessarily lead to management change; RMI has to be actively in place in order for behaviour to change. The presence of this mediator confirms the structure of the conceptual model developed in this study. Management attitude influences management intention, which in turn, leads to behaviour. This finding explains why, despite responsible tourism policies and initiatives, transformation is not at a satisfactory level. Tourism businesses do not have a negative attitude towards responsible tourism; rather they are facing too many constraints in their business environment to feel empowered enough to implement change. This finding confirms previous tourism research by Sirakaya (1997), who found that although there is an assumption that attitudes lead to behaviour, the link is often not clear. Consequently the need to implement change mechanisms, as highlighted by social marketing literature, becomes evident.

\section{Perceived and actual barriers of adopting RTM}

There are several reasons why Cape Town tourism businesses feel constrained to act on their positive attitudes. The research findings show that RTM is perceived by tourism business managers and owners as expensive and onerous. Perceived costs of RTM include inferior quality standards of smaller suppliers (61\% agree), concerns about safety and security of these suppliers (60\% agree) and too high costs of changing operational systems (for example putting in place waste management systems or employing from the local surrounding community $-61 \%$ agree). On a positive note, tourism businesses do realise the potential benefits of implementing RTM. On average $80 \%$ of study respondents agreed that RTM leads to enhanced employee morale and performance, improves company reputation and is an effective marketing tool. Low levels of RTM, despite businesses acknowledging the benefits of responsible tourism, shows that perceived costs are outweighing perceived benefits. RTM practices will only be adopted if financial and psychological costs of implementation can be reduced. There is a desperate need to create channels for change. To address this shortcoming, CTT in 2008, commissioned an audit of the tourism supply chain in the Cape Town metropole. Policies to affect change in RTM usually focus on tourism service providers and end users (Frey, 2007: 319). Recommendations often centre on how both consumers and producers of tourism products can act in a more sustainable manner. Whilst this approach is not incorrect, it is often associated with both perceived and real costs as this study shows. One underestimated area of potential positive change is the supply chain (Ciliberti, Pontrandolfo \& Scozzi, 2008). Income generated from supplying the tourism industry is estimated to be as large if not surpassing that stemming from direct employment in the tourism industry (Lengefeld \& Stewart, 2004; Mitchell \& Ashley, 2007; ). Moreover, supply chains have the opportunity to be more community-based, use different skill sets and thus spread tourism benefits to a larger pool of people.

Analysis of the data also showed that the organisational environment tourism businesses operate in strongly affects their attitude towards, and willingness to adopt RTM. Findings show that the level of competition has a negative moderating effect on the relationship between management intention and performance confirming previous findings by Jaworski and Kohli (1993). As competition increases, profit margins decrease and the scope to implement change is reduced. A further measure of the competitive environment is consumer turbulence, namely the degree to which consumers' demands change. Consumer turbulence was found to positively moderate the statistical relationship between management intention and non-financial performance. RTM is consumer-driven. Consequently, businesses that are more market-sensing, in other words, gather, use and interpret accurate information about consumers and the market conditions (Day, 1994) are more likely to employ responsible management practices.

\section{Understanding of government initiatives}

Results of the study also show that understanding of government initiatives such as the RTMSA (Spenceley et al., 2002) and the BEE Tourism Charter and Scorecard of South Africa (DEAT, 2005) promoting responsible tourism is low with $44 \%$ of respondents understanding the RTMSA poorly or not at all. These policies are the formal framework on which the transformation agenda and sustainable tourism development in South Africa is founded. The low level of understanding of tourism business managers who are tasked to put in place the recommendations of these policies is disconcerting and would partially explain the lack of transformation in the tourism industry. Educating the tourism sector about the relevance and practical benefits of these policies is therefore a prerequisite in bringing about the desired behaviour change. In addition, the research highlighted the lack of confidence the tourism business sector has in the efficacy of government policies. Sixty per cent of the businesses do not believe that government is helping them put in place responsible tourism practices and only $17 \%$ see the government's efforts positively. This perception of government effectiveness and support negatively influences to what extent businesses believe it to be worthwhile to adopt responsible management practices, especially in the light of research findings that confirm a positive association between understanding and support of government initiatives and a positive attitude towards social responsibility (Gilg et al., 2005; Yaman \& Gurel, 2006). 
Not only is understanding important for implementation, but research findings of this study show that the level of understanding of the RTMSA positively influences the level of perceived RTM benefits with $\beta=0.18$. If the tourism industry accepts that RTM leads to business benefits, adoption will become a strategic decision; rather than a moral obligation.

Another indication of the level of RTM awareness and implementation is the endorsement of the FTTSA trademark. The majority $(80 \% / 169$ businesses $)$ of respondents do not have FTTSA accreditation with only $14 \%(\#=29)$ businesses at the time indicating that they have been able to meet the FTTSA's stringent criteria. The qualitative research results suggest that Cape Town tourism providers perceived the FTTSA accreditation process to be complex, costly and not necessarily beneficial for business.

A mere $13 \%$ of study respondents indicated that they have a HIV/Aids policy in place. This number is disconcertingly low given the urgency regarding this pandemic in South Africa. Tourism is highly labour-intensive and peopleorientated and should therefore be at the forefront of ensuring that employees and customers have the necessary information and protection with regards to HIV/Aids.

\section{Marketing implications}

In terms of achieving the wider socio-economic mandate of tourism development in South Africa, adopting RTM practices will significantly contribute to bringing about transformation and addressing the inequalities of the past. Globally, RTM is in line with reaching the objectives of poverty reduction and unemployment as outlined by the Millennium Development Goals (MDGs), as well as addressing issues around climate change and scarce resource management. Finally, RTM is a tool for the local tourism industry to develop a strategic competitive advantage, realise ROI, diversify the product-offering and provide a unique and authentic tourism experience. This paper has indentified various factors, which are negatively affecting management attitude, intention and behaviour. The following section recommends how some of these challenges can be addressed.

Perceived costs of using small suppliers are too high. These costs include insufficient quality standards and quantity capacity, as well as ordering and delivery ease. Many of the tourism businesses indicated that they would use smaller community suppliers if these factors could be addressed. CTT has commissioned an audit of its membership base to address this problem and compile a database of RTM suppliers to facilitate business between members. Longterm capacity building, mentoring and skills transfer to small medium and micro enterprises (SMMEs) will be essential for economic growth and social upliftment.

The lack of safety and security when using small suppliers is a key deterrent for many tourism businesses. Occasional attacks on tourists in informal settlements, corruption, and overcharging tourists are making tour operators and other tourism providers apprehensive of using community suppliers. The Department of Tourism (formerly the Department of Environmental Affairs \& Tourism) is currently developing a strategy to address the safety and security of visitors and implement safety measures for tourism service providers. Besides the actual problems of crime and violence, there is also the challenge around the perception of crime. In many instances, local community tourism service providers have a safe and secure productoffering. However, an isolated incident can tarnish the image and reputation of the industry and can have significant negative spin-off effects (George, 2003).

The level of competition in tourism is high. One way of addressing international competition is to create a uniquely local experience. There is often a misconceived perception that overseas travellers demand the same products and services in the visiting destination as they receive at home. Whilst there is no doubt that quality standards have to be high, research clearly indicates that tourists are looking for new, authentic and different cultural experiences (Bachleitner \& Zins, 1999; King 2002; Cohen, 2004: 66; Pérez \& Nadal, 2005). Employing RTM practices makes use of local heritage and community knowledge. By engaging with different people and cultures, a richer and more competitive product-offering is developed. Clearly, the question of superior customer service and quality cannot be ignored and it is imperative that local community service providers are trained and skilled. Education in the tourism industry, as is the case in most of South African business sectors, needs to be placed continuously at the centre of development.

The perception by tourism businesses of lacking government support has to be changed. It is imperative that the private sector believes in the competence and will of government to bring about change. Transformation and the achievement of the goals set out by the BEE Tourism Charter and Scorecard (DEAT, 2005), as well as the much wider objectives of poverty alleviation, job creation and environmental sustainable management, will be achieved only through public-private co-operation. Government support needs to be carefully communicated and the effects monitored. By showing tourism businesses what is being done practically to support them, goodwill results and consequently improved buy-in to adopt RTM practices.

The $21^{\text {st }}$ century consumer is increasingly critical of the activities of businesses and watchful of his or her impacts on local communities. Adhering to ethical management practices and adopting a triple-bottom- line accounting approach ensures that businesses safeguard against potential risks with regards to their reputation and image. In a highly competitive environment where product and price parity reigns, purchasing decisions are often made based on brand reputation, recognition or emotional connection. RTM ensures transparency and a balance between financial, social and environmental objectives. Such sensitivity will contribute towards safeguarding the 
business against negative publicity and help maintain the tourism product it relies on.

\section{Conclusions}

The statistical relationships in the conceptual framework, which were developed based on previous research, are partially confirmed by this study. The data proves that in emerging markets the direct relationship between management attitude and behaviour does not necessarily hold. This is largely due to a lack of resources. Using social marketing strategies to enable change are clearly needed to facilitate the transformation of the tourism industry for a globally competitive, socially equitable and naturally sustainable future.

As the field of responsible tourism management (RTM) grows, more opportunities for future research can be identified. The benefits that accrue to tourism organisations managing their business in a responsible manner are often realised only in the medium to long-term. A longitudinal research study would allow for testing of cause and effect relationships. Evidence, for example, of the financial benefit of RTM to businesses, would be a powerful tool in motivating for more responsible management. Furthermore, whereas this paper has focused on the supply-side of the tourism industry, a market analysis is required. It is necessary to uncover the exact magnitude and nature of responsible tourism demand. In order to be market-sensing, it is critical that tourism organisations understand consumers' needs, perceptions and attitudes, and the obstacles facing consumers with regards to responsible tourism management practices.

\section{References}

Allen, G. \& Brennan, F. 2004. Tourism in the new South Africa - social responsibility and the tourist experience. New York: I. B. Tauris.

Allen, C., Machleit, K., Kleine, S. \& Notani, A. 2005. 'A place for emotion in attitude models', Journal for Business Research, 58(4): 494-499.

Andreasen, A. 2000. 'Intersector transfer of marketing knowledge'. In Bloom, P. \& Gundlach, G. Eds. 2000. Handbook of marketing and society. Washington: Sage Publications.

Bachleitner, R. \& Zins, A. 1999. 'Cultural tourism in rural communities: The resident's perspective', Journal of Business Research, 44(3): 199-209.

Becker-Olsen, K, Cudmore, B. \& Hill, R. 2006. 'The impact of perceived corporate social responsibility on consumer behaviour', Journal of Business Research, 59(1): 46-53.
Bellows, K. 2007. 'Pioneer of geotourism: Jonathan B. Tourtellot on sustainable travel',. National Geographic Traveler. 23(8):12-13.

Blackwell, R., Miniard, P. \& Engel, J. 2006. Consumer behaviour. $10^{\text {th }}$ Edition. Canada: Thomson South-Western.

Brennan, M., Rae, N., \& Parackal, M. 1999. 'Survey-based experimental research via the web: Some observations', Marketing Bulletin, 4(10): 83-92.

Budeanu, A. 2005. 'Impacts and responsibilities for sustainable tourism: A tour operator's perspective', Journal of Cleaner Production, 13(2): 89-97.

Burgess, S. \& Nyajeka, P. 2006. Market orientation and performance at the 'base of the pyramid': The case of Zimbabwean retailers. Market Science Institute, Working Paper.

Burgess, S. \& Steenkamp, J. 2006. 'Marketing renaissance: How research in emerging markets advances marketing science and practice', International Journal of Research Marketing, 23(4): 337-356.

Ciliberti, F., Pontrandolfo, P. \& Scozzi, B. 2008. 'Investigating corporate social responsibility in supply chains: A SME perspective', Journal of Cleaner Production, 16(15): 1579-1588.

Cohen, E. 2004. Contemporary tourism: Diversity and change. Amsterdam: Elsevier.

Cooper, D. \& Schindler, P. 2006. Marketing research. New York: McGraw-Hill Irwin.

Day, G. 1994. 'The capabilities of market-driven organisations', Journal of Marketing, 58(4): 37-52.

Department of Environmental Affairs and Tourism (DEAT). 2002. 'Responsible tourism guidelines'. [online] URL:http://www.info.gov.za.

Department of Environmental Affairs and Tourism (DEAT). 2005. 'Tourism BEE Charter and Scorecard'. [online] URL:http://www.info.gov.za.

De Jong, M., Steenkamp, J., Fox, J. \& Baumgartner, H. 2008. 'Using item response theory to measure extreme response style in marketing research: A global investigation', Journal of Marketing Research, 45(1): 104115 .

Dolnicara, S. \& Leisch, F. 2008. 'Selective marketing for environmentally sustainable tourism', Tourism Management, 29(4): 672-680.

Etheredge, J. 1999. 'The perceived role of ethics and social responsibility: An alternative scale structure', Journal of Business Ethics. 18(1): 51-64. 
Fennell, D. 2001. 'A content analysis of ecotourism definitions', Current Issues in Tourism, 4(5):403-421.

Frey, N. 2007. 'Managing tourism responsibly'. In George, R. (Ed.). Managing tourism in South Africa. Cape Town: Oxford University Press.

Fricker, S. Galesic, M., Tourangeau, R., \& Yan, T. 2005. 'An experimental comparison of web and telephone surveys', Public Opinion Quarterly, 69(3):370-392.

George, R. 2003. 'Tourists' perceptions of safety and security while visiting Cape Town', Tourism Management, 24(5): 575-585.

Gilg, A., Barr, S. \& Ford, N. 2005. 'Green consumption or sustainable lifestyles? Identifying the sustainable consumer', Futures, 37(6): 481-504.

Goodwin, H. \& Francis, J. 2003. 'Ethical and responsible tourism: Consumer trends in the UK', Journal of Vacation Marketing, 9(3):271-284.

Goodwin, H. \& Venu, V. 2008. 'The Kerala Declaration on responsible tourism: Incredible India', Second International Conference on Responsible Tourism in Destinations, Kochi.

http://www.responsibletourism2008.org/keraladeclaration.p $\mathrm{hp}$

Hoskisson, R., Eden, L., Chung, M. \& Wright, M. 2000. 'Strategy in emerging economies', Academy of Management Journal, 43(3):249-267.

Hunt, S., Wood, V., \& Chonko, L. 1989. 'Corporate ethical values and organisational commitment in marketing', Journal of Marketing, 53:79-90.

Jaworski, B. \& Kohli, A. 1993. 'Market orientation: antecedents and consequences', Journal of Marketing, 57:53-70.

King, J. 2002. 'Destination marketing organisations connecting the experience rather than promoting the place', Journal of Vacation Marketing, 8(2): 105-108.

Kirca, A. 2004. 'Institutionalisation of market orientation in the subsidiaries of multinational corporations'. Unpublished doctoral dissertation, University of South Carolina.

Kotler, P. \& Roberto, E. 1989. Social marketing: strategies for changing public behaviour. New York: The Free Press, Macmillan, Inc [Nicole Frey].

Kotler P, Roberto, N. \& Lee, N 2002. Social marketing: Improving the quality of life. $2^{\text {nd }}$ Edition. California: Sage Publications.
Krippendorf, J. 1987. The holiday makers: Understanding the impact of leisure and travel. Oxford: ButterworthHeinemann.

Lengefeld, K. \& Stewart, R. 2004. 'All-inclusive resorts and local development, World Travel Market'. [online] URL:www.propoortourism.org.uk. Accessed 13 July 2008.

Maignan, I., Ferrell, O. \& Hult, G. 1999. 'Corporate citizenship: Cultural antecedents and business benefits', Journal of the Academic Marketing Science, 27(4): 455469.

Maignan, I. \& Ferrell, O. 2004. 'Corporate social responsibility and marketing: An integrative framework', Journal of Marketing Science, 32(1): 3-19.

Martin, S. \&, Jucker, R. 2005. 'Educating earth-literate leaders', Journal of Geography in Higher Education, 29(1): 19-29.

Middleton, V. 1998. Sustainable tourism - A marketing perspective. Oxford: Butterworth-Heinemann.

Mitchell, J. \& Ashley, C., 2007. 'Can tourism offer propoor pathways to prosperity?' ODI Briefing Paper 22. Overseas Development Institute. [online] URL:http://www.odi.org.uk.

Morris, D, Fenton, M. \& Mercer, Z. 2004. 'Identification of national trends in nursing education through the use of an online survey', Nursing Outlook, 52(5): 248-254.

Pender, L. \& Sharpley, R. (Eds.). 2005. The management of tourism. London: Sage Publications Ltd.

Pérez, E. \& Nadal, J. 2005. 'Host community perceptions: A cluster analysis', Annals of Tourism Research, 32(4): 925-941.

Pizam, A. \& Mansfeld, Y. (Eds). 1999. Consumer behaviour in travel and tourism. New York: The Haworth Press, Inc.

Porter, M. \& Kramer, M. 2006. 'Strategy \& society: The link between competitive advantage and corporate social responsibility', Harvard Business Review, 84(12): 78-92.

Robin, D. \& Reidenbach, R. 1987. 'Social responsibility, ethics, and marketing strategy: Closing the gap between concept and application', Journal of Marketing, 51(1): 4458 .

Robinson, L. 1998. 'The seven doors social marketing approach'. Conference paper read at the Waste Educate 98 Conference [online] URL:

http://www.media.socialchange.net.au/strategy/7_Doors_M odel html. Accessed 8 February, 2009. 
Rogerson, M. \& Visser, G. 2004. Tourism and development issues in contemporary South Africa. Pretoria: Africa Institute of South Africa.

Roth, M. 2005. 'Validating the use of the Internet survey techniques in visual landscape assessment - An empirical study from Germany', Landscape and Urban Planning, 78(3): 179-192.

Rothschild, M. 1999. 'Carrots, sticks, and promises: A conceptual framework for the management of public health and social issue behaviour', Journal of Marketing. 63: 2437.

Ruekert, R. 1992. 'Developing a market orientation: An organisational strategy perspective', International Journal of Research in Marketing, 9: 225-245.

Scheyvens, R. 1999. 'Ecotourism and the empowerment of local communities', Tourism Management, 20(2): 245-249.

Schianetz, K., Kavanagh, L. \& Lockington, D. 2007. 'The learning tourism destination: The potential of a learning organisation approach for improving the sustainability of tourism destinations', Tourism Management, 28(6): 14851496.

Schwartz, S. 1994. 'Are there universal aspects in the content and structure of human values?' Journal of Social Issues, 50(4): 19-45.

Schwartz, S. 2004. Mapping and interpreting cultural differences around the world. In H. Vinken, J. Soeters \& P. Ester (Eds.), Comparing cultures: Dimensions of culture in a comparative perspective. Leiden, The Netherlands: Brill.

Sen, S. \& Bhattacharya, C. 2001. 'Does doing good always lead to doing better? Consumer reactions to corporate social responsibility', Journal of Marketing Research, 38(2): 225-243.

Shafer, W., Fukukawa, K. \& Lee, G. 2007. Values and the perceived importance of ethics and social responsibility: the U.S. versus China. Journal of Business Ethics. 70(3): 265-284.

Singhapakdi, A., Vitell, K., Rallapalli, K., \& Kraft, K. 1996. 'The perceived role of ethics and social responsibility: A scale development', Journal of Business Ethics. 11: 745-752.

Sirakaya, E. 1997. 'Attitudinal compliance with ecotourism guidelines', Annals of Tourism Research, 24(4): 919-950.

South African Tourism. 2009. 2008 Annual Tourism Report. Johannesburg: South African Tourism.

Spenceley, A. 2005. 'Nature-based tourism and environmental sustainability in South Africa', Journal of Sustainable Tourism, 13(2): 136-144.
Spenceley, A. 2007. 'Responsible tourism practices by South African tour operators', International Centre for Responsible Tourism - South Africa. [online] URL: http://anna.spenceley.co.uk/Papers.htm

Spenceley, A., Relly, P., Keyser, H., Warmeant, P., McKenzie, M., Mataboge, A. Norton, P., Mahlangu, S. \& Seif, J. 2002. Responsible tourism manual for South Africa. Pretoria: Department of Environmental Affairs and Tourism, July 2002.

Tearfund. 2001. 'Tourism: Putting ethics into practice - a report on the responsible business practices of $65 \mathrm{UK}$-based tour operators'. [online] URL: http://www.tearfund.org.

United Nations (UN). 1987. The Brundland report. [online] URL:www.un.org. Accessed August 2008.

United Nations World Tourism Organisation (UN-WTO). 2007. www.world-tourism.org. Accessed July 2007.

Van der Merwe, M. \& Wöcke, A. 2007. 'An investigation into responsible tourism practices in the South African hotel industry', South African Journal of Business Management, 38(2): 1-15.

Weeden, C. 2001. 'Ethical tourism: An opportunity for competitive advantage', Journal of Vacation Marketing, 8(8): 141-153.

Wharton, C., Hampl, J., Hall, R., \& Winham, D. 2003. 'PCs or paper-and-pencil: Online surveys for data collection', Journal of the American Dietetic Association, 103(11): 1458-1459.

Wheeler, M. 1995. 'Tourism marketing ethics: An introduction', International Marketing Review, 12(4): 3849.

Wijk, J. \& Persoon, W. 2006. 'A long-haul destination: Sustainability reporting among tour operators', European Management Journal, 24(6): 381-39.

World Travel and Tourism Council (WTTC). 2006. 'South Africa: The 2007 travel \& tourism economic research'. [online] URL:www.wttc.org. Accessed August 2006.

Yaman, H. \& Gurel, E. 2006. 'Ethical ideologies of tourism marketers', Annals of Tourism Research, 33(2): 470-489.

Yarona Management Consulting. 2007. 'Baseline study to determine the state of transformation in the tourism industry'. [online]

URL:http://www.tourismbeecharter.co.za. 